\title{
CAPITAL-BASED PENSION FUNDS: THE QUESTION OF RISK SHARING
}

\section{Abstract}

Capital-based pension funds are built from the contributions of their participants and are invested in financial assets. Failed investments cause a fund's capital to shrink, which generates a risk of low pension benefits and/or the insolvency of the fund. The risk can be shared between contributors, pension fund management companies, and the state (under a mandatory pension funds regime). This article attempts to emphasise that, particularly in the case of old-age insurance, the problem of who runs the most risk is pivotal and deserving of greater concern than the issue of whether the rate of return on investment is high enough. The aim is to draw attention to this rather neglected aspect of the recent reforms of the old-age insurance industry.

The method relies on an ordered analysis founded on a review of the relevant subject literature. The point is made that the change from the Defined Benefit (DB) to the Defined Contribution (DC) formula shifts most of the risk onto contributors. On the other hand, this change makes the business relatively safe for private insurers and banks and reduces pressure on the public finance balance sheet. The shift from DB to DC schemes is rather common in Europe, hence the main issues tackled in the article are relevant to a fairly big group of countries (including Poland).

The article discusses the issue of risk-sharing in reference to the modern experience of Chile, a country that pioneered changes with respect to capital-based pensions and DC schemes. It concludes that the element of social solidarity recently introduced into the Chilean system brings some relief to low-income workers and also supports the longevity of the fully-funded Defined Contribution system.

Keywords: pension reforms, funded pensions, Chile, Defined Contribution formula. JEL Classification: P16, B52. 


\section{Introduction}

Old-age security is largely placed in the insurance industry, where risk constitutes a crucial value. In Latin American countries as well as in East European countries, the insurance principle can be said to be a consequence of structural pension reforms. The first wave of these reforms originated in Chile, and in the course of the 1980s came to embrace the populations of many other Latin American countries. The second wave, heavily supported by World Bank expertise, reached Poland and numerous countries in Eastern Europe at turn of the 1990s and 2000s. Meanwhile, in the developed countries one could observe a change which, though of a much less radical nature, seemed to be of the same orientation.

The radical standard consisted of twin reforms. The first introduced capital-based pension funds, while the other completely changed the formula for calculating pensions. The idea was to convert pension savings into contributions to privately-managed capital funds. This meant a shift in old-age security systems away from public pension schemes on a pay-as-you-go (PAYG) basis towards individual pension plans on a capital basis. The latter means that funds are used as capital and invested in financial assets, the investment being managed by private companies. In Chile, financing on a PAYG-basis was gradually phased out after 1982, and the country moved towards a fully-funded pension system.

Another fundamental change was the completely different formula for calculating pensions, which determines risk-sharing in the industry. Here, risk is seen as financial responsibility for investment outcomes. Fundamental to risk-sharing in the pension industry is the principle that governs benefits and contributions, suffice it to say that the former principle was replaced with a so-called Defined Contribution (DC) formula. Strikingly, this change, being a common component of reforms aimed at introducing capital-based pension funds, is somewhat absent in public and economic debate or is eclipsed by the issue of whether the rate of return of capital-based pension funds is high enough.

By contrast, this article attempts to demonstrate that the question of who is most exposed to risk seems to be of the utmost importance, particularly in the old-age insurance industry. It discusses the issue of risk-sharing in reference to the modern experience of Chile, a country that pioneered radical changes with respect to both strands of pension reform. Next, it discusses the distributional meaning of the Defined Contribution formula. Then it briefly reviews the most recent reforms in Chile and concludes they 
are not going to constitute a counter-revolution as regards the formula for calculating pensions. The Chilean case supports the observation, which may have more general application, that introducing state guarantees into a pension system and thus delivering relief to the lowest social strata may, paradoxically, preserve the system of risk-sharing that makes those strata suffer in the first place.

\section{Risk-sharing under a Defined Contribution Formula}

As pension funds are built from the contributions of their participants and are used as capital to be invested in financial assets, the risk of failed investments can be shared between contributors, fund management companies, and the state (Barr \& Diamond 2009). The point to be made here is that replacing the Defined Benefit formula with a Defined Contribution formula has shifted most of the risk onto contributors.

This risk demonstrates itself in two ways. The outcome of failed investments is that the pension capital shrinks, which generates a risk of low pension benefits and/or the insolvency of the fund. In the event of pension fund insolvency, the question of risk-sharing must discriminate between funds accumulated on a mandatory-insurance basis and those accumulated on a voluntary-insurance basis. Namely, if insolvency affects contributions accumulated as part of mandatory insurance, the implicit responsibility of the state is more obvious. However, let us focus on the more common situation when pension fund operations see shrinking pension capital due to failed investments and when the risk of low pension benefits arises. In such a case, the share of the state depends on an explicit declaration concerning the amount of the minimum pension as acknowledged by the state. Normally, such guarantees apply to pension savings under public management as well as to privately-managed pension funds accumulated on a compulsory basis. The risk to individual contributors or would-be pensioners is even more clear. As far as fund management companies are concerned, they used to be cushioned from this risk with help of certain institutional arrangements, which will be discussed below using the Chilean example.

Let us see which of the parties concerned is most exposed to risk under the new formula for calculating pensions. Under the previous Defined Benefit formula, the value of pension benefit, as calculated in accordance with the rules imposed by the state, was actually guaranteed by the state, which ran the risk that inflows to the system would not balance the outflows due to benefits. Under the new Defined Contribution 
formula, the contribution parameters are precise. Contributed savings are transparently registered on individual member accounts and are invested in securities and on the financial markets as well; the value of the pension benefits depends on the return on capital and is therefore uncertain (Bodie, Marcus \& Merton 1988). Thus, the shift to the DC formula reduces pressure on the public finance balance sheet (Ostaszewski 2001). Under this rule, the obligations to pensioners match the available funds. In effect, it is the individual contributor who bears the risk of a failed investment (Barr \& Diamond 2008). This consequence of introducing the DC formula can be partly mitigated with a solution restricted to mandatory pension savings, namely, an extremely low retirement pension can be topped up to a minimum level by the state.

The DC formula makes activities in the pension industry extremely attractive to management companies. It makes the business safe for private insurers and banks, and it also improves the pension balances for public-fund management agencies. From this micro-perspective one can better comprehend a generalisation made by a certain widely respected institution. According to the International Monetary Fund, "over the last 30 years, the fully funded Defined Contribution formula system has raised national savings, aided the development of capital markets, and reduced fiscal risks" (IMF 2016). Bearing in mind that the first achievement might rather be due to mandatory pension savings, we cannot doubt that the change was in favour of financial firms and the public finances.

Under the DC formula, most of the risk of a failed investment has been shifted to would-be pensioners, and this is another side of the coin. The distributional and political consequences of the change in the formula for calculating pensions have perhaps been easily overlooked in the public debate, and the issue seems to have been marginalised by the reformers.

\section{How Individual Risk Exposure Was Limited in Chile}

Since the 1981 reform, Chile has remained the country most determined to convert pension savings into privately-managed capital funds. Recently, more than $80 \%$ of pension savings in Chile are invested under the rules governing this retirement scheme, basically on a mandatory-insurance basis $^{1}$. In terms of capital, the system allows for concentration of savings

\footnotetext{
${ }^{1}$ The Chilean retirement system between 1981 and 2008 was composed of two pillars. The first pillar was administered by the state, and the privately-administered second pillar comprised mandatory contributions under AFP management. The former included the PAYG system and
} 
amounting to close to $70 \%$ of GDP and for those savings to be managed by new investors. The companies that manage mandatory pension funds, so-called AFPs (adminstradoras de fondos de pensiones), invest the pension savings in securities such as shares, sovereign bonds, mortgage bonds, etc., and a substantial portion is invested abroad ${ }^{2}$.

The system has worked under the DC formula since 1981. The portfolio risk under such a system was acutely revealed during the recent international financial crisis. Within a very short time, Chilean contributors saw the value of the capital they had accumulated in their individual accounts shrink dramatically. This value, which reached $64.4 \%$ of GDP in 2007, plummeted to $52.8 \%$ of GDP in 2008.

The year 2008 witnessed a modification of risk-sharing. This was accomplished exclusively due to the re-introduction of systemic guarantees by the state, while the DC formula remained intact. The reforms under the presidency of Michelle Bachelet were undertaken in two steps - in 2008 and 2015. Their core significance can be summarised as rebuilding social security and re-introducing publicly-administered programmes on behalf of retirees. Under the 2008 reform of the Social Security Administration it was officially admitted that mandatory old-age insurance had to be bolstered with pension benefits paid from general taxation. In particular, the poorest $60 \%$ of contributors to AFPs were given a supplementary or additional pension benefit known as APS (aporte provisional solidario). The modified structure of the pension system is shown in Figure 1.

How dramatic the situation must have been before the crisis struck is indirectly shown by the numbers in the Table 1 . These refer to the replacement rate, which is the average pension relative to the average salary during the insured's working life. Despite an improvement after the first wave of reform, total replacement rates in Chile remained close to or below the internationally-acknowledged minimum of $45 \%$, as Table 1 shows. Before this improvement, benefits paid out from the system to the bulk of pensioners were below the national social minimum. The 2007 projections suggested that the monthly income of about one half of pensioners would be little more than half the minimum salary of 390 USD (Mesa-Lago \& Bertranou 2016, p. 7). The 2008 reform resulted in a substantial increase in

\footnotetext{
the heavily-subsidised army and police pension schemes as well as a retirement income safety-net (the guaranteed minimum pension). The contributory pillar lacked voluntary collective savings accounts, and in 2016 these were reported to be still heavily under-developed (Bertranou 2016, p. 16).

${ }^{2}$ Recently, more than $40 \%$ of assets under AFP management were invested abroad, and only $11 \%$ in local equity (Credit Suisse 2014, p. 3, 5).
} 
average pensions due to tax-financed pension benefits being targeted at the lowest-income beneficiaries. Table 1 presents the extent of this improvement between 2007 and 2014 as well as the relevance of the APS, which is in fact a state subsidy. In 2015, on average, the value of the APS represented nearly $80 \%$ of total old-age income. This increase favoured the lowest-income beneficiaries the most and made the real contributory pension increase substantially on average.

\begin{tabular}{|c|c|c|c|}
\hline \multicolumn{2}{|l|}{ Pillar } & Non-contributory & $\begin{array}{l}\text { Contributory (only fully } \\
\text { funded capital accounts) }\end{array}$ \\
\hline \multicolumn{2}{|c|}{ Administration } & $\begin{array}{l}\text { Social Security } \\
\text { Administration }^{\mathrm{a}}\end{array}$ & $\begin{array}{l}\text { Pension management } \\
\text { companies }^{\mathrm{b}} \text { and } \\
\text { insurance companies }\end{array}$ \\
\hline \multicolumn{2}{|c|}{ Financing } & General tax revenues & $\begin{array}{l}\text { Workers' contributions } \\
\text { according to taxable wage }\end{array}$ \\
\hline \multirow[t]{3}{*}{ Benefits } & $\begin{array}{l}\text { Poorest } 60 \%, \text { no } \\
\text { contributions required }\end{array}$ & Basic pension benefit, $\mathrm{PBS}^{\mathrm{c}}$ & - \\
\hline & $\begin{array}{l}\text { Poorest } 60 \% \text {, some } \\
\text { contributions required }\end{array}$ & $\begin{array}{l}\text { Supplementary or additional } \\
\text { pension benefit, APS }\end{array}$ & $\begin{array}{l}\text { Self-financed pension } \\
\text { benefit, } \mathrm{PCI}^{\mathrm{e}}\end{array}$ \\
\hline & Fully contributory & - & $\begin{array}{l}\text { Self-financed pension } \\
\text { benefit, PCI }\end{array}$ \\
\hline
\end{tabular}

${ }^{\mathrm{a}}$ Instituto de Prevision Social, ${ }^{\mathrm{b}} \mathrm{AFPs}-$ adminstradoras de fondos de pensiones, ${ }^{\mathrm{c}} \mathrm{PBS}-$ pension basica solidaria,${ }^{\mathrm{d}}$ APS - aporte provisional solidario, ${ }^{\mathrm{e}} \mathrm{PCI}$ - pension autofinanciada; pension benefit derived from individual pension savings,

Fig. 1. Pension Benefits under the 2008 Reform

Source: based on Bertranou (2016, p. 14, annex 2).

Table 1. Median Replacement Rates, Ten Last Salaries, 2007-2014

\begin{tabular}{l|c|c|c}
\hline \multicolumn{1}{c|}{ Specification } & Total & Men & Women \\
\hline Without APS (self-financed) & 34 & 48 & 24 \\
\hline With APS (aporte provisional solidario) & 45 & 60 & 31 \\
\hline
\end{tabular}

Source: based on Mesa-Lago and Bertranou (2016, table 2, p. 8).

Although the improvement as a consequence of the 2008 reform seems to be modest by European welfare standards, the new arrangements limited individual risk exposure. Contributors can have their asset losses, like those during the 2008-2009 financial crisis, cushioned by a basic pension or by an additional pension benefit with a social floor (see Figure 1). Extremely low retirement benefits are topped up to minimum level from tax revenues. However, it should be stressed that this social floor covers a fraction of the 
system's beneficiaries, namely, the poorest $60 \%$ of retirees and would-be pensioners. Those with work income above a certain level contribute to the fully-funded individual saving accounts scheme and bear the full risk (Bertranou 2016, p. 10).

The supporters of fully-funded pensions in Chile maintain that individual risk exposure was already limited thanks to mandatory pensions engineering (Knowledge@Wharton 2009). Since the start of their operations, the AFPs have been obliged to meet a minimum level of return for each of the managed funds. In the event that an AFP fails to meet the guarantee obligation, it must transfer the difference between the actual return and the minimum level from its own reserve fund. This idea of "benchmarking" is familiar to everyone who is acquainted with the Polish counterpart of the Chilean AFPs, namely, the OFEs. However, in spite of the improvements in the Chilean arrangement, it turned out to be quite a soft "stick". The sanction is only triggered if a pension fund's return is below the minimum level for three consecutive years, which makes it easy to manipulate. Moreover, the benchmark for AFPs is the weighted average return of all funds, so it is enough to follow the investment choices of the biggest AFPs, which try to remain close to the average and thus be spared any compensation on behalf of affiliates of the managed fund (Hyde 2014, p. 16-17).

There is, however, a novelty in mandatory pensions engineering that seems to be a direct response to the question of excessive risk exposure of contributors. Fund affiliates can choose from among different income funds, with young people being supposed to invest in variable income funds with a relatively high risk, while older people are supposed to choose funds with lower profitability and thus be less exposed to possible losses. Although this sounds like a good idea when presented by policy-makers and experts, the loopholes are easy to detect in practice. What makes academic commentators sceptical is the asymmetric information where a regular client and a fund-employed advisor are concerned (Garcia-Huitron \& van Leuvensteijn 2015). Another barrier to rational choice on the part of clients is the limited understanding of unskilled people.

As far as the management companies engaged in mandatory old-age insurance are concerned, they are largely free of the risk associated with failed investments that could adversely affect their incomes. Since 1981, the AFPs collect fund-affiliates' contributions, credit them to workers' accounts, and invest these monies according to the regulations set by the government. They also contract with insurance companies to provide survivorship and 
disability insurance to their fund affiliates. For these services, each AFP charges an administrative commission and a premium on its own behalf and on behalf of the insurance company. The basis of these fees, which is the affiliates' contributions to the funds and fund's assets, is secured by the system. Since affiliation to an AFP fund is mandatory, AFPs do not need to compete for savings with other financial institutions such as banks or stock exchanges; in this sense, they are legally privileged.

Moreover, the concentration of assets in the mandatory old-age insurance industry has progressed. The number of AFPs dropped from 21 to 5 between 1994 and 2008, with the concentration of contributors in the three major AFPs jumping from approximately $67 \%$ to more than $86 \%$ (Mesa-Lago \& Bertranou 2016, p. 9). Inevitably, this makes the Big Three free of anxiety in the face of benchmarking and the possibility of losing monies of their own under this arrangement.

Consequently, instead of desirable market competition and a decrease in administrative costs, average fees increased between 1981 and 2008. High fees, which the AFPs charge to account holders, result in profits that are much larger than in other sectors of Chile's financial services industry. Between 1991 and 2004, AFPs earned an average return of 27\% on assets. In 2005, administrative fees represented a record 91\% of AFPs' income (Kritzer 2008, p. 77, 79).

What makes the business safe for AFPs aggravates the risk of low benefits to contributors. As the official supervisory institution, the Social Security Administration, stated in 2008: "Account holders have had lower net rates of return (and smaller pensions) in part because AFPs have charged high administrative fees" (Kritzer 2008, p. 77).

The year 2008 witnessed a minor change in the contributory component and a more significant change in the non-contributory pillar. The reform, recommended by presidential advisers (the Marcel Commission) and fully approved by parliament, entailed the funding or co-funding of benefits from tax revenues being extended from a very small fraction of the population to the poorest $60 \%$ of the population. Thus, a social protection floor was established, which is regarded as one of the major accomplishments of the reform. According to the reformers, contributions to the system from general tax revenues are to be extended while leaving the AFP component at the core of the system. A new report by experts from the Bravo Commission, presented to President Bachelet in September 2015, proposed to maintain the status quo with possible increases in tax-financed benefits. Another option proposed to introduce a social insurance component, thus reducing 
the size of the individual savings component along with increased scope for the basic pension benefit (PBS). Such scenarios ${ }^{3}$ seem to go along with the view of pension management companies and conservative think tanks, supported by foreign experts and international organisations, which highlight the need to maintain the status quo and allow for some change in the volume of financing and parametric changes only ${ }^{4}$ (Bertranou 2016, p. 3). Even a new social insurance component would not signal a revolution; it should be considered rather as an attempt to support the longevity of the AFP pillar thanks to state contributions from general taxation. For those who believe the state should be an arbiter between the private sector and the interests of society, this finding may come as a great disappointment.

To summarise: the reform of the Chilean pension system follows the line of extending the safety net with the help of increased tax-financing, leaving the contribution-benefit formula intact. The shift from the DB formula to the DC formula, in addition to the privatisation of pension funds, constituted the basis of the structural reform in Chile in 1981. In 2015, however, the Bravo Commission's assessment of the pension system, though obviously fair in enumerating the problems (Barr \& Diamond 2016, p. 6), did not touch the issue at all. While attitudes towards the contributory pillar managed by private AFPs were rather clear-cut, a change in the contribution-benefit relationship remains out of the question. Since no sort of investment is risk-free, "the only thing left (...) is to wait until the recessionary economic cycle is over...”. Interestingly enough, this argument was put forward by Professor Fernando Bravo (Knowledge@Wharton 2009, p. 2, 4), who was a member of the Marcel Commission and subsequently head of the Bravo Commission. The shift back from the DC formula to the DB formula did not win the support of the Bravo Commission because it received only one expert's vote (Oręziak 2016) .

\footnotetext{
${ }^{3}$ Most probably, the Chilean government and the congress will attempt to implement some of the specific proposals but may leave decisions about the global proposals (status quo or social security) until the end of 2017.

${ }^{4}$ Parametric and institutional changes that would constitute challenges to AFPs are recommended, like setting maximum allowable losses for abnormal investment periods, relating charges and commissions to the real performance of administrators, along with simultaneous and/or shared monitoring of the system's operations by all parties: the AFPs, their contributors, and the government.

${ }^{5}$ Professor Leokadia Oręziak was invited to the Commission by President Bachelet after having published a book entitled Open Pension Funds. Catastrophic Privatisation of Pensions in Poland (Oręziak 2014), which may be of interest to Polish readers.
} 


\section{Conclusion}

The Chilean case shows how easy it is to prevent public debate on the issue of the formula for calculating pensions. At the same time, the Chilean system is one which creates extreme individual risk exposure for those who contribute their savings to it. The radical reform of 1981 abolished the employer's contribution and shifted responsibility onto workers, who saw their taxable income diminish due to mandatory pension savings deposited in order to be capitalised and also due to commissions and premiums paid to management companies and insurance companies. They bear the portfolio risk revealed by fluctuations in the value of capital accumulated in individual accounts. The system gives them no chance to opt out in the face of a steady decline in the annual real rate of return (from $20.6 \%$ to $8.8 \%$ since the inception of the system ${ }^{6}$ ). With employers as outsiders and with management companies rewarded without any direct link to the rate of return on investment, those who suffer losses are the contributor-employees?

Bringing the state back into the Chilean pension system does not mean any fundamental change in risk-sharing on behalf of contributors. Rebuilding the social security solidarity mechanism, relatively modest in scope as it is, seems to be the most relevant recent change with respect to risk-sharing in the Chilean pension system. It brings some relief to low-income workers who, having a basic pension benefit guaranteed by the Social Security Administration, need not to be exposed to investment risk any more. And it sees the state bringing back general taxation revenues into the pension system.

Regarding the main issue tackled in this paper, the current new reforms are not going to signal a counter-revolution with respect to the formula for calculating pensions ${ }^{8}$. So far, they have left the foundations of the system intact (Barr \& Diamond 2016, p. 8). The companies who manage mandatory pension funds under the DC rule remain safe in the light of recent reform projects. Paradoxically, by guaranteeing the lowest pension benefits and thus providing relief to the lowest social strata, the state supports the longevity of the fully-funded Defined Contribution formula system.

\footnotetext{
${ }^{6}$ This data was retrieved from Mesa-Lago and Bertranou (2016, p. 12).

${ }^{7}$ This grossly unfair position is acutely realised by the Chileans; it prompted nationwide protests to demand new reform of the country's pension system.

${ }^{8}$ Argentina, for instance, implemented a radical return to the previous Defined Benefit formula and public PAYG system in 2008, having eliminated the private component and having transferred private savings to the Social Security Administration.
} 
Apparently, universal old-age insurance is a very special branch of finance due to its original social mission. The traditional core idea of designing old-age insurance has been security, which is provided in the form of an income (pension) paid to a person of retirement age. In other words, an income high enough to protect against poverty has been at the heart of the mission. This is the essence of the Defined Benefit formula. Basically, public insurers could provide benefits consistent with the social minimum, mostly due to financing on a PAYG basis, since this system of financing allowed for income redistribution. According to the DB formula, the benefit may be based on the worker's final wage and length of service. However, it does not depend on the amount of assets accumulated in the person's name, and the risk to pension assets of varying rates of return ultimately falls on the sponsor. In the traditional system the public management agency was backed by the state budget, which was the sponsor. Under the structural pension reforms, the basic relationship between contributions and benefits was changed in the system as a whole. The guaranteed social minimum was withdrawn from part of the pension industry and the risk of old-age poverty was shifted from the managing agent to the contributor, with extremely low retirement benefits being topped up to a minimum level from social aid resources. Under the DC formula, the benefit is determined by the amount of capital paid in towards a person's pension. The consequent change in risk-sharing among the contributors to the funds, the fund management companies, and the state is fundamental to how the reform is evaluated by the parties involved.

\section{Bibliography}

Barr, N. and Diamond, P. (2008), "Reforming Pensions". ISSR Draft, November, http:// econ.lse.ac.uk/staff/nb/Barr_Diamond_crr.pdf (accessed: 9 May 2017).

Barr, N. and Diamond, P. (2009) "Reforming Pensions: Principles, Analytical Errors and Policy Directions”. International Social Security Review 62 (2), https://doi.org/10.1111/ j.1468-246x.2009.01327x.

Barr, N. and Diamond, P. (2016) "Reforming Pensions in Chile". Polityka Spoteczna 1: 4-9, https://www.ipiss.com.pl/?lang=enecon.lse.ac.uk/staff/nb/Barr_and_Diamond_2016_ Chile.pdf (accessed: 9 May 2017).

Bertranou, F. (2016) "Pension Benefits in Chile: Is It Possible to Improve Adequacy and Solidarity?". A joint ILO/IZA conference in partnership with leading G20 think tanks, ILO headquarters, Geneva, Switzerland, 10-11 March (work in progress - 29 February). 
Bodie, Z., Marcus, A. J. and Merton, R. C. (1988) "Defined Benefit versus Defined Contribution Pension Plans: What Are the Real Trade-offs?" in Z. Bodie, J. B. Shoven, and D. A. Wise Pensions in the U.S. Economy. Chicago: University of Chicago Press, pp. 139-62.

Credit Suisse (2014) “Chile: Pension Fund Snapshot as of May 2014”. Economics Research, 19 June, http://www.credit-suisse.com/researchandanalytics (accessed: 13 October 2017).

Garcia-Huitron, M. and van Leuvensteijn, M. (2015) "International Pension Reform Diffusion: A Tale about Chile and the Netherlands Trying to Learn from Each Other". Het Verzekerings-Archief 4: 196-200, https://www.apg.nl/en/pdfs/chilean-example-indutch-pension-debate.pdf (accessed: 13 October 2017).

Hyde, M. (2014) "Classical Liberalism and Conservatism: How Is Chile's 'Private' Pension System Best Conceptualised?". Reader in Work \& Pensions. School of Government, Plymouth University, Plymouth, UK, https://c4ss.org/wp-content/uploads/2014/10/ pensions.pdf (accessed: 13 October 2017).

IMF (2016) "Chile: Staff Concluding Statement of the 2016 Article IV Mission". IMF, www.imf.org/en/News/Articles/2016/11/02/MS110216-Chile-Staff-ConcludingStatement-of-the-2016-Article-IV-Mission (accessed: 6 February 2017).

Knowledge@Wharton (2009) “The Fall of Pension Funds in Chile: A Lesson from the Downturn”. Knowledge@Wharton, 25 February, http://knowledge.wharton.upenn. edu/article/the-fall-of-pension-funds-in-chile-a-lesson-from-the-downturn/ (accessed: 6 February 2017).

Kritzer, B. E. (2008) “Chile's Next Generation Pension Reform”. Social Security Bulletin 68 (2): 69-84.

Mesa-Lago, C. and Bertranou, F. (2016) "Pension Reforms in Chile and Social Security Principles, 1981-2015”. International Social Security Review 69 (1): 25-45, January/ March, http://onlinelibrary.wiley.com/doi/10.1111/issr.12093/full (accessed: 6 February 2017).

Oręziak, L. (2014) OFE. Katastrofa prywatyzacji emerytur w Polsce [Open Pension Funds. Catastrophic privatisation of pensions in Poland]. Warsaw: Książka i Prasa.

Oręziak, L. (2016) “OFE nie jest świętością" [Open Pension Funds are not sacred]. GazetaPrawna.pl, 10 January, http://serwisy.gazetaprawna.pl/emerytury-i-renty/ artykuly/916543,wywiad-prof-oreziak-ofe-nie-jest-swietoscia-chile.html (accessed: 6 February 2017).

Ostaszewski, K. M. (2001) "Macroeconomic Aspects of Private Retirement Programs". North American Actuarial Journal 5 (3), p. 52-64, https://doi.org/10.1080/10920277. 2001.10595998.

\section{Abstract}

\section{Kapitałowe fundusze emerytalne i kwestia rozłożenia ryzyka}

Kapitałowe fundusze emerytalne są tworzone ze składek swoich członków celem ich inwestowania na rynkach finansowych. Nietrafione inwestycje powodują zmniejszenie kapitału emerytalnego, co rodzi ryzyko niskich świadczeń emerytalnych lub niewypła- 
calności funduszu. Ryzyko może się rozkładać na płacących składki, na firmy zarządzające funduszami i na państwo (kiedy oszczędzanie z kapitałowymi funduszami jest przymusowe). W artykule stwierdzono, że centralny problem - szczególnie w ubezpieczeniach na starość - stanowi to, kto ponosi największy ciężar ryzyka. Kwestia ta zasługuje na większą uwagę niż rentowność systemu. Celem jest zwrócenie uwagi na ten mało zauważany element współczesnych reform systemów ubezpieczeń emerytalnych.

Zastosowana metoda polega na uporządkowanej analizie, opartej na znajomości literatury istotnej dla podjętego tematu. Zamiana formuły liczenia świadczeń emerytalnych, czyli przejście od zdefiniowanego świadczenia do zdefiniowanej składki, oznacza zwiększenie obciążenia ryzykiem dla płacących składki (ubezpieczonych). Z drugiej strony ta zmiana czyni branżę emerytalną relatywnie bezpieczną dla prywatnych firm ubezpieczeniowych i banków, a także zmniejsza napięcie bilansowe w sektorze finansów publicznych. Przechodzenie od zasady zdefiniowanego świadczenia do formuły zdefiniowanej składki jest w Europie raczej powszechne, a zatem postawione kwestie mają znaczenie dla dużej grupy krajów, w tym Polski.

W artykule rozważa się zagadnienie podziału ryzyka, odnosząc się do współczesnego doświadczenia Chile - kraju, który jest pionierem zmian zarówno w sensie kapitałowych funduszy emerytalnych, jak i formuły zdefiniowanej składki. Analiza przypadku prowadzi do wniosku, że komponent solidarności społecznej wprowadzony ostatnio do systemu chilijskiego, ograniczając ryzyko pracowników o najniższych dochodach, zarazem podtrzymuje żywotność systemu opartego na kapitalizacji emerytur i na zasadzie zdefiniowanej składki.

Słowa kluczowe: reformy emerytalne, kapitalizacja emerytur, Chile, formuła zdefiniowanej składki. 